OPEN ACCESS

Edited by:

Thomas Efferth,

Johannes Gutenberg-Universität

Mainz, Germany

Reviewed by:

Luísa Custódio,

Centro de Ciências do Mar (CCMAR),

Portugal

Funda Nuray Yalcin, Hacettepe University, Turkey

*Correspondence:

Maqsood A. Siddiqui maqsoodahmads@gmail.com

Specialty section: This article was submitted to

Ethnopharmacology, a section of the journa Frontiers in Pharmacology

Received: 04 April 2018 Accepted: 02 July 2018

Published: 23 July 2018

Citation:

Siddiqui MA, Ali Z, Chittiboyina AG and Khan IA (2018) Hepatoprotective

Effect of Steroidal Glycosides From Dioscorea villosa on Hydrogen Peroxide-Induced Hepatotoxicity in HepG2 Cells.

Front. Pharmacol. 9:797. doi: 10.3389/fphar.2018.00797

\section{Hepatoprotective Effect of Steroidal Glycosides From Dioscorea villosa on Hydrogen Peroxide-Induced Hepatotoxicity in HepG2 Cells}

\author{
Maqsood A. Siddiqui 1,2*, Zulfiqar Ali ${ }^{3}$, Amar G. Chittiboyina ${ }^{3}$ and Ikhlas A. Khan ${ }^{3,4}$ \\ ${ }^{1}$ Zoology Department, College of Science, King Saud University, Riyadh, Saudi Arabia, ${ }^{2}$ Al-Jeraisy Chair for DNA Research, \\ Zoology Department, College of Science, King Saud University, Riyadh, Saudi Arabia, ${ }^{3}$ National Center for Natural Products \\ Research, School of Pharmacy, The University of Mississippi, Oxford, MS, United States, ${ }^{4}$ Department of BioMolecular \\ Sciences, School of Pharmacy, The University of Mississippi, Oxford, MS, United States
}

Dioscorea villosa, commonly known as "Wild Yam" and native to North America, is well documented for its pharmacological properties due to the presence of steroidal glycosides. However, the hepatoprotective potential of these compounds has not been studied so far. The present investigation was aimed to study the hepatoprotective effect of the steroidal glycosides from $D$. villosa against $\mathrm{H}_{2} \mathrm{O}_{2}$, a known hepatotoxin, in human liver cell line (HepG2). Cytotoxicity assessment was carried out in cells exposed to various concentrations $(10-50 \mu \mathrm{M})$ of compounds for $24 \mathrm{~h}$ using MTT assay and morphological changes. All tested compounds were known and among them, spirostans (zingiberensis saponin I, dioscin, deltonin and progenin III) were found to be cytotoxic whereas, furostans (huangjiangsu A, pseudoprotodioscin, methyl protobioside, protodioscin, and protodeltonin) were non-cytotoxic. Further, HepG2 cells were pretreated with biologically safe concentrations $(10,30$, and $50 \mu \mathrm{M})$ of noncytotoxic compounds and then cytotoxic $(0.25 \mathrm{mM})$ concentration of $\mathrm{H}_{2} \mathrm{O}_{2}$. After $24 \mathrm{~h}$, cell viability was assessed by MTT and NRU assays, while morphological changes were observed under the microscope. The results showed that treatment of HepG2 cells with compounds prior to $\mathrm{H}_{2} \mathrm{O}_{2}$ exposure effectively increased cell viability in a concentration-dependent manner. Furthermore, huangjiangsu A, pseudoprotodioscin, methyl protobioside, protodioscin, and protodeltonin at $50 \mu \mathrm{M}$ increased GSH level and decreased intracellular ROS generation against $\mathrm{H}_{2} \mathrm{O}_{2}$-induced damages. The results from this study revealed that compounds isolated from $D$. villosa have hepatoprotective potential against $\mathrm{H}_{2} \mathrm{O}_{2}$-induced cytotoxicity and $\mathrm{ROS}$ generation and could be promising as potential therapeutic agents for liver diseases.

Keywords: Dioscorea villosa, Dioscoreaceae, steroidal glycosides, $\mathrm{H}_{2} \mathrm{O}_{2}$, cytotoxicity, ROS generation

\section{INTRODUCTION}

The liver is the largest glandular organ, and plays a key role in the regulation of various physiological processes in the human body (Bechmann et al., 2012). It is the most important site of intermediary metabolism responsible for the detoxification and excretion of various substances like xenobiotics by altering and expelling toxins and wastes (Chaudhari and Mahajan, 2016). Owing to 


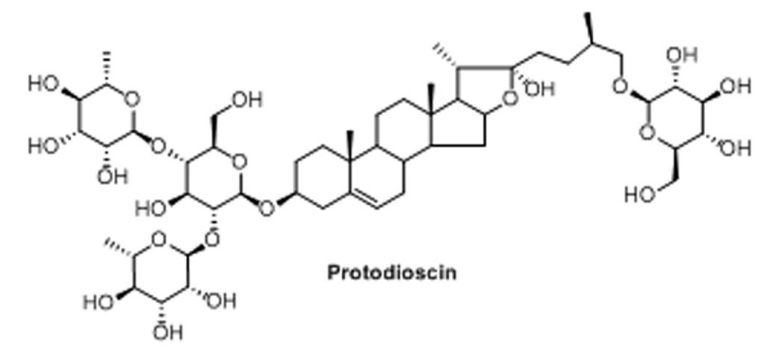

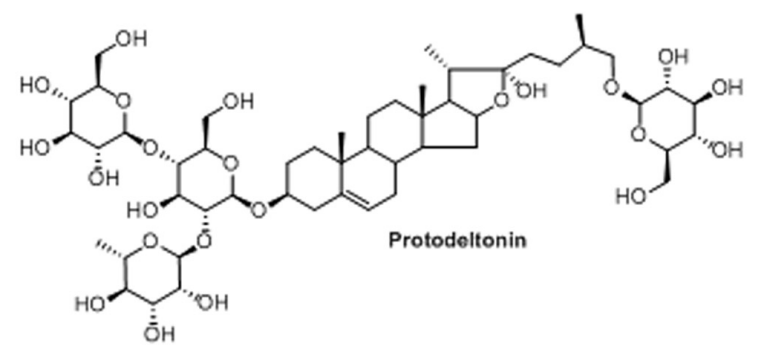

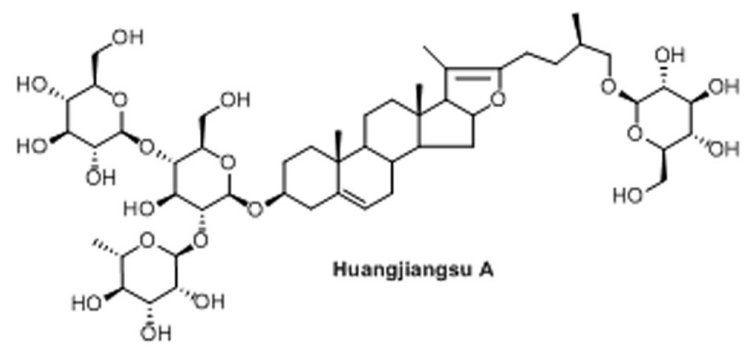

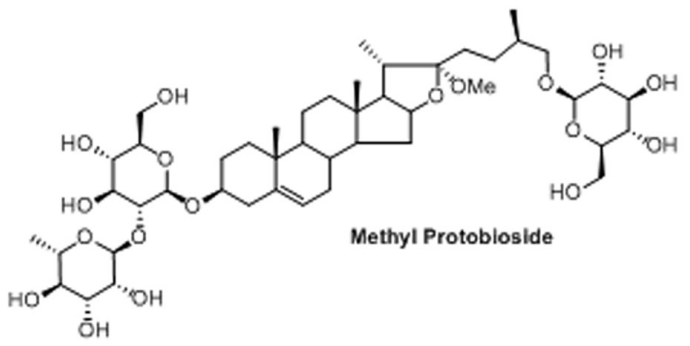

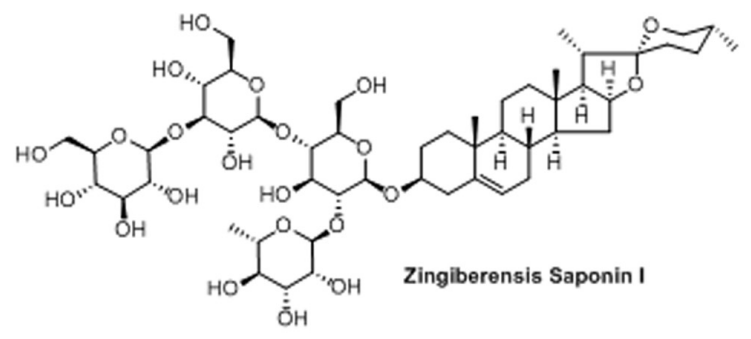

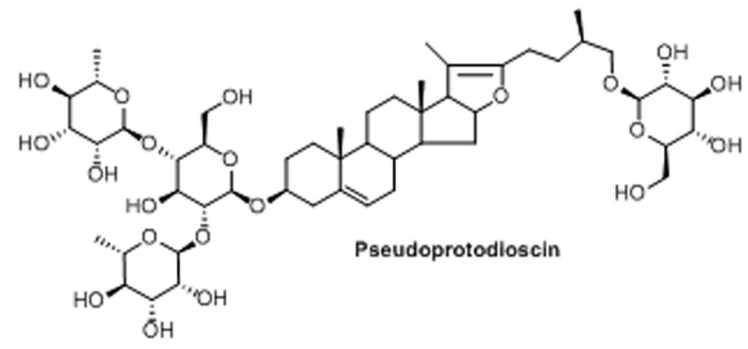

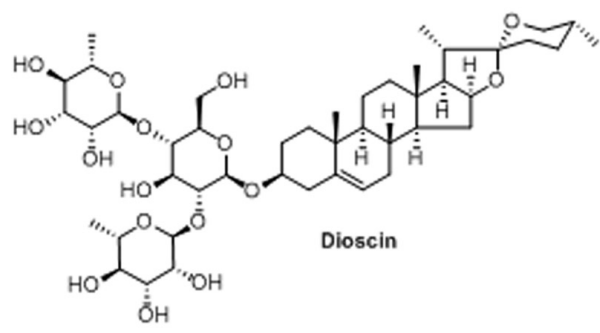

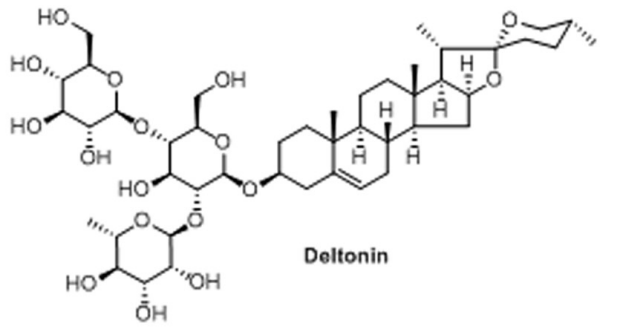

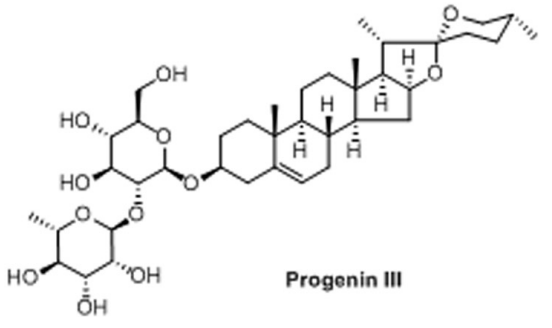

FIGURE 1 | Structures of isolated compounds from Dioscorea villosa.

continuous exposure to the toxicant via the portal blood circulation, the liver is highly susceptible to damage by xenobiotics, drugs, and hazardous substances (Sharma et al., 2011). Due to handling the metabolism of various proteins, lipids, carbohydrates, secretion of bile, and storage of vitamins, it is considered as one of the most vital organs (Bechmann et al., 2012). The liver diseases are a global health problem therefore, the maintenance of healthy liver is imperative for human health (Haidry and Malik, 2014). A variety of chemicals, such as tert-butyl hydroperoxide (t-BHP), $\mathrm{D}$-galactosamine/lipopolysaccharide, carbon tetrachloride $\left(\mathrm{CCl}_{4}\right)$, acetaminophen, alcohol, and hydrogen peroxide can cause potential damage to the liver cells leading to progressive dysfunction (Simeonova et al., 2014). Oxidative stress is a redox 

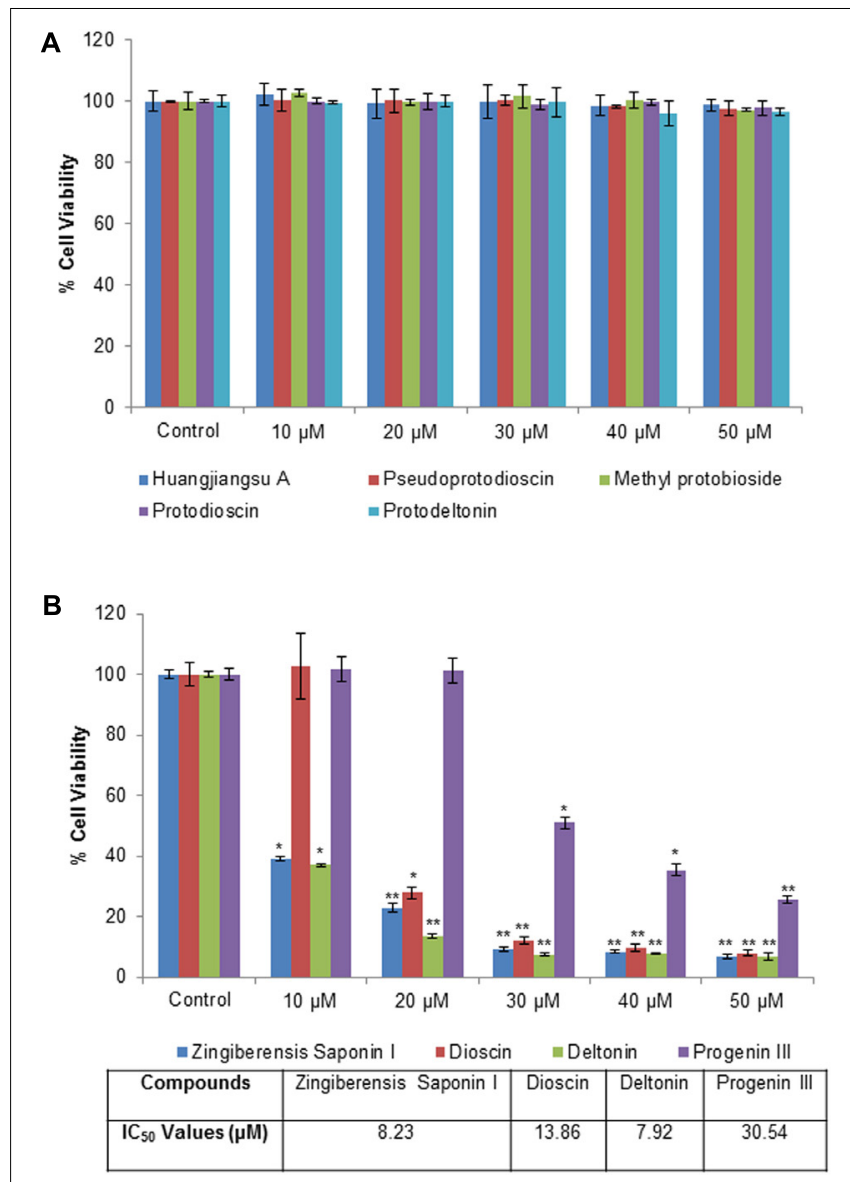

FIGURE 2 | Cytotoxicity assessment by MTT assay in HepG2 cells following the exposure of different concentrations of compounds isolated from Dioscorea villosa. All values are given as mean \pm SD. (A) Non-cytotoxic compounds and (B) Cytotoxic compounds. ${ }^{*} p<0.05$, ${ }^{* *} p<0.01$ versus control.

imbalance between pro-oxidant, i.e., the production of reactive oxygen species (ROS) and antioxidant defense counteracting the reactive intermediates and initiating the cellular damage (Videla, 2009). Oxidative stress is also known to be involved in the mechanism of hepatotoxicity and pathogenesis (Li et al., 2015). Overproduction of ROS results in oxidative stress, a deleterious process that can be an important mediator of damage to cell structures, lipids, membranes, proteins, and DNA (Ray et al., 2012). Hydrogen peroxide $\left(\mathrm{H}_{2} \mathrm{O}_{2}\right)$ is well known to increase the levels of intracellular ROS generation and causes cellular oxidative damage (Cheong et al., 2016). Several evidences also showed that $\mathrm{H}_{2} \mathrm{O}_{2}$-induced cytotoxicity in human liver cells (Al-Sheddi et al., 2016; Gao et al., 2016) and has been linked with various alterations including anti- and pro-apoptosis proteins and caspases (Cheong et al., 2016). Therefore, $\mathrm{H}_{2} \mathrm{O}_{2}$ was chosen in this study as an inducer of oxidative stress and cytotoxicity in the human liver cell line (HepG2). Despite the recent therapeutic advances and significant development of modern medicine, hepatic diseases remain a health problem worldwide (Hong et al., 2015). Thus, the search for new therapeutic agents to treat liver diseases is still in demand. Many synthetic drugs have been demonstrated to be strong radical scavengers, but they are also carcinogenic and cause liver damage (Cheong et al., 2016). Due to the fact that the available drugs can cause damage to healthy hepatic cells, the new researches have been focused to protect hepatic diseases and reduce adverse side effects by using natural compounds isolated from the plants. A literature survey revealed that many plant extracts and their constituents have constantly shown hepatoprotective effects (Jiménez-Arellanes et al., 2016). It has also been reported that pure compounds and extracts from plants possess good antioxidant activity against chemically induced liver damage (Pereira et al., 2016).

Dioscorea villosa L. (Family: Dioscoreaceae), a tuber vegetable commonly known as "Wild Yam," is native to North America and has been recommended for menopausal symptoms and menstrual complaints (Komesaroff et al., 2001). Dioscorea plants are rich in steroidal saponins and sapogenins. Over 50 steroid saponins of furostane-, spirostane-, and pregnanetype skeletons have been isolated and characterized from various Dioscorea species, which have been reported to be the major physiologically active constituents in yams (Hayes et al., 2007; Ali et al., 2013a,b). Among the isolated constituents of D. villosa, the cytotoxic activities of diosgenin and dioscin have been studied against a number of cancer cell lines (Kim et al., 2014; Aumsuwan et al., 2016). Hypocholesterolemic and hypoglycemic effects of dioscin have also been reported (McAnuff et al., 2005) and no subchronic toxicity of dioscin was observed in vivo with a high dose for 3 months (Xu et al., 2012). A number of preclinical and mechanistic studies have been reported supporting the antitumor potential of dioscin (Aumsuwan et al., 2016). The epigenetic mechanism of the anticancer effect of wild yam root extract (Aumsuwan et al., 2015) and a detailed study on anticancer potential of dioscin on cell viability, invasion, migration, and wound healing in an invasive breast cancer cell line has been reported (Aumsuwan et al., 2016). These studies demonstrated that constituents of D. villosa possess pharmacological potential especially antitumor effects. To the best of our knowledge, there are no reports available on their hepatoprotective effect. Therefore, this study was aimed to investigate the hepatoprotective effect of the constituents of $D$. villosa against $\mathrm{H}_{2} \mathrm{O}_{2}$-induced cytotoxicity and oxidative stress in HepG2 cell line. HepG2 cell line is well reported to be involved in the metabolism (Kim et al., 2011) and have been proven to be a good model system for cytotoxicity assessment and cyto-protective potential of various compounds against the toxic substances (González et al., 2017).

\section{MATERIALS AND METHODS}

\section{Chemicals and Consumables}

Dulbecco's modified Eagle medium (DMEM) culture medium, trypsin, fetal bovine serum (FBS), and antibiotics/antimycotic solution were procured from Invitrogen, Life Technologies, Grand Island, NY, United States. Plastic wares and other consumables used in the study were purchased from Nunc, 


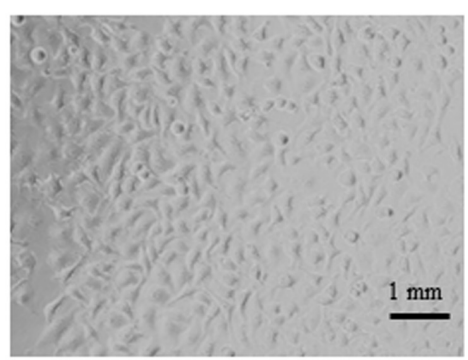

Control
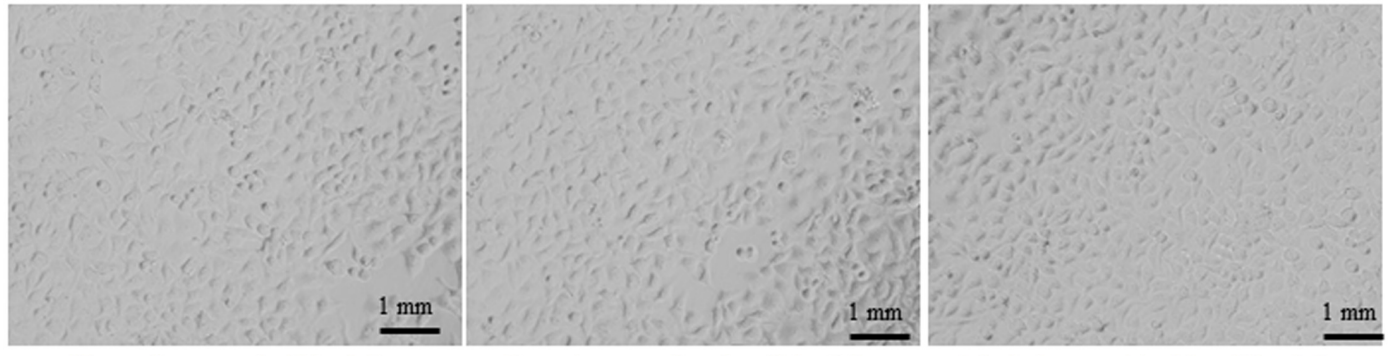

Huangjiangsu $\mathrm{A}(50 \mu \mathrm{M})$

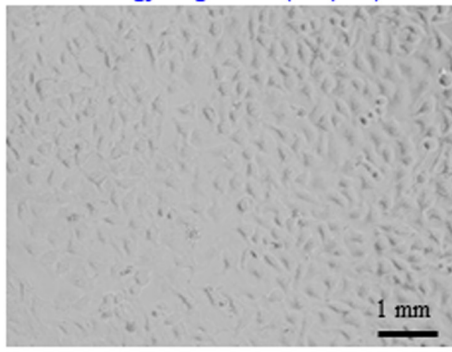

Pseudoprotodioscin $(50 \mu \mathrm{M})$

Methyl protobioside $(50 \mu \mathrm{M})$
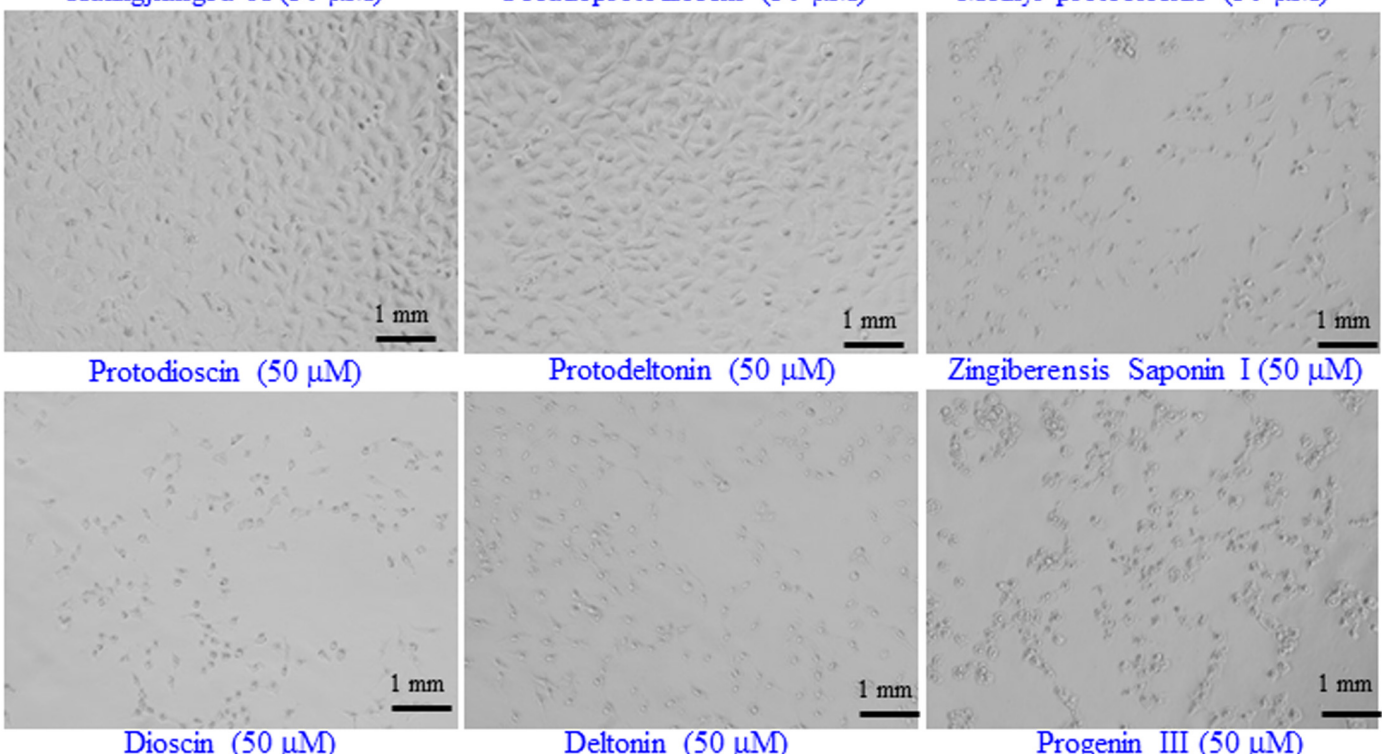

FIGURE 3 | Representative images of the morphological changes in HepG2 cells after the exposure of the compounds isolated from Dioscorea villosa. All the images were acquired using a phase contrast inverted microscope at $20 \times$ magnification. Each scale bar $=1 \mathrm{~mm}$.

Roskilde, Denmark. $\mathrm{H}_{2} \mathrm{O}_{2}$ and all specified chemicals and reagents were purchased from Sigma Chemical Company Pvt., Ltd., St. Louis, MO, United States.

\section{Plant Material}

Root powder of Dioscorea villosa L. was purchased from Starwest Botanicals, United States. A sample specimen of the purchased material (No. 9412) was deposited at the National Center for Natural Products Research, The University of Mississippi.

\section{Extraction and Isolation}

Root powder $(0.9 \quad \mathrm{~kg})$ was extracted with $\mathrm{MeOH}$ $(3.0 \mathrm{~L} \times 4 \times 24 \mathrm{~h})$ at room temperature. Following the removal of the solvent, a gummy residue $(\mathrm{MeOH}$ extract, $75 \mathrm{~g})$ was obtained. An aliquot (55 g) was subjected to size exclusion chromatography using Sephadex LH-20 $(17 \times 10 \mathrm{~cm})$ and eluted with $\mathrm{MeOH}$ to furnish 2 parts, A $(7.0 \mathrm{~L}, 45.2 \mathrm{~g})$ and $\mathrm{B}(5.0 \mathrm{~L}$, $9.4 \mathrm{~g})$. Part A $(30 \mathrm{~g})$ was separated by normal phase column chromatography (NPCC) using silica gel $(30 \times 10 \mathrm{~cm})$ into 12 fractions (A1-A12) with lower layer of $\mathrm{CHCl}_{3}-\mathrm{MeOH}-\mathrm{H}_{2} \mathrm{O}$ (13:7:2) [A1 (0.5 L, $782 \mathrm{mg})$, A2 (1.0 L, $730 \mathrm{mg})$, A3 (0.5 L, $304 \mathrm{mg})$, A4 (0.5 L, $767 \mathrm{mg})$, A5 (0.5 L, $490 \mathrm{mg})$, A6 (0.5 L, $1.8 \mathrm{~g}), \mathrm{A} 7(1.0 \mathrm{~L}, 657 \mathrm{mg})$, A8 (1.0 L, $2.8 \mathrm{~g})$, A9 (1.0 L, $1.9 \mathrm{~g})$, A10 (1.5 L, $4.4 \mathrm{~g}), \mathrm{A} 11(1.5 \mathrm{~L}, 4.5 \mathrm{~g})$, and A12 (1.5 L, $5.9 \mathrm{~g})]$. Fractions A3 and A4 were individually subjected to NPCC [silica gel $(87 \times 1.3 \mathrm{~cm})$, EtOAc- $\left.\mathrm{CHCl}_{3}-\mathrm{MeOH}-\mathrm{H}_{2} \mathrm{O}(10: 6: 4: 1), 1.0 \mathrm{~L}\right]$ 


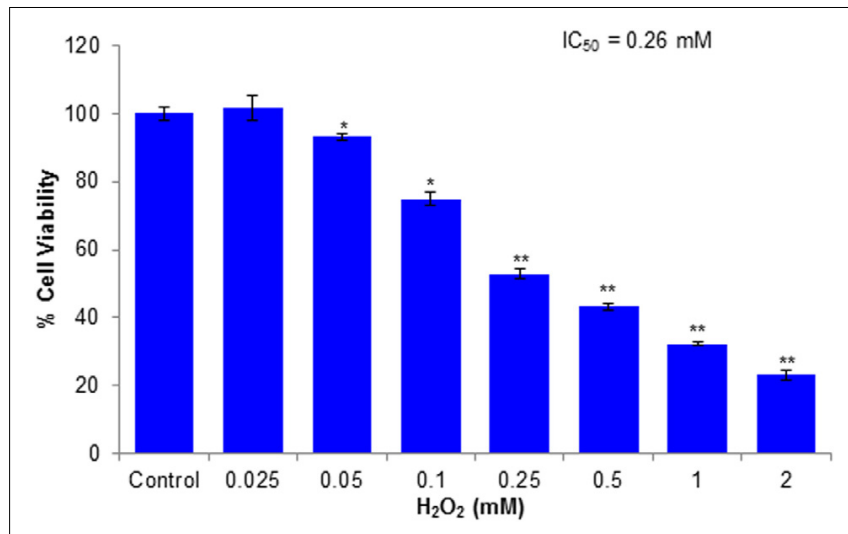

FIGURE 4 | Cytotoxicity assessments by MTT assay in HepG2 cells following the exposure of various concentrations of $\mathrm{H}_{2} \mathrm{O}_{2}$ for $24 \mathrm{~h}$. All values are given as mean $\pm \mathrm{SD} .{ }^{*} p<0.05,{ }^{*} p<0.01$ versus control.

to yield progenin III (375 mg) and dioscin (126 mg). Deltonin (785 mg) and zingiberensis saponin I (90 mg) were obtained from fractions $\mathrm{A} 6$ and $\mathrm{A} 8$, respectively, as $\mathrm{MeOH}$ insoluble materials. Methyl protobioside $(325 \mathrm{mg}$ ) was purified from the $\mathrm{MeOH}$ soluble part of fraction A8 by NPCC [silica gel $(87 \times 2.5 \mathrm{~cm})$, $\mathrm{CHCl}_{3}-\mathrm{MeOH}-\mathrm{H}_{2} \mathrm{O}$ (32:8:1), $4.5 \mathrm{~L}$ ] and RPC [RP-18 silica gel $(37 \times 2.5 \mathrm{~cm})$, acetone- $\left.\mathrm{H}_{2} \mathrm{O}(1: 1), 0.5 \mathrm{~L}\right]$. Fraction A9 was resolved by NPCC [ silica gel $(37 \times 2.5 \mathrm{~cm})$, lower layer of $\mathrm{CHCl}_{3}$ $\mathrm{MeOH}-\mathrm{H}_{2} \mathrm{O}$ (13:7:2), $\left.2.7 \mathrm{~L}\right]$ into three subfractions (A9a-A9c). Pseudoprotodioscin (45 mg) and protodioscin (212 $\mathrm{mg}$ ) were purified from subfraction A9c (665 mg) by RPC [RP-18 silica gel $(45 \times 2.5 \mathrm{~cm})$, acetone- $\left.\mathrm{H}_{2} \mathrm{O}(2: 3), 0.7 \mathrm{~L}\right]$. Huangjiangsu A $(646 \mathrm{mg})$ and protodeltonin $(1.3 \mathrm{~g})$ were purified from fraction A11 by RPC [RP-18 silica gel $(50 \times 3.7 \mathrm{~cm})$, acetone- $\mathrm{H}_{2} \mathrm{O}(2: 3)$, $2.5 \mathrm{~L}]$.

\section{Cell Culture}

HepG2 cell line was purchased from ATCC and was cultured in DMEM, supplemented with 10\% FBS, $0.2 \%$ sodium bicarbonate and antibiotic/antimycotic solution ( $1 \mathrm{~mL} / 100 \mathrm{~mL}$ of medium). Cells were grown in a $\mathrm{CO}_{2}$ incubator at $37^{\circ} \mathrm{C}$. Prior to the experiments, viability of cells was assessed using the previously described protocol (Siddiqui et al., 2008). Batches showing more than $98 \%$ cell viability and passage number of cells between 22 and 24 were used in this study.

\section{Experimental Design}

For cytotoxicity assessments, HepG2 cells were exposed to various concentrations $(10-50 \mu \mathrm{M})$ of the $D$. villosa compounds and $\mathrm{H}_{2} \mathrm{O}_{2}(0.025-2 \mathrm{mM})$ for $24 \mathrm{~h}$. To study the cytoprotective potential, HepG2 cells were pretreated with biologically safe concentrations $(10,30$, and $50 \mu \mathrm{M})$ of non-cytotoxic D. villosa compounds (huangjiangsu A, pseudoprotodioscin, methyl protobioside, protodioscin, and protodeltonin) and then cytotoxic concentrations of $\mathrm{H}_{2} \mathrm{O}_{2}(0.25 \mathrm{mM})$ were added in the medium containing compounds for $24 \mathrm{~h}$. Further, for protective potential of compounds on GSH level and intracellular ROS generation against $\mathrm{H}_{2} \mathrm{O}_{2}$, cells were pre-exposed to $50 \mu \mathrm{M}$ of the D. villosa compounds for $24 \mathrm{~h}$ then, $\mathrm{H}_{2} \mathrm{O}_{2}(0.25 \mathrm{mM})$ for $24 \mathrm{~h}$.

\section{Preparation of Stock Solutions of Compounds}

The stock solutions of all the compounds $(25 \mathrm{mM})$ were prepared in dimethylsulfoxide (DMSO) and diluted in culture medium to reach the desired concentrations. The final DMSO concentration used for the experiments was not more than $0.2 \%$ and this was used as control.

\section{Cytotoxicity Assessment by MTT Assay}

The MTT assay was performed for cytotoxicity assessments following the method described (Siddiqui et al., 2008). In brief, HepG2 cells were seeded in 96-well plates at a density of $1 \times 10^{4}$ cells per well and allowed to grow overnight. Then, cells were exposed to various concentrations of compounds of D. villosa for $24 \mathrm{~h}$. After the exposure, $50 \mu \mathrm{g}$ MTT was added in each well and plates were incubated further for $4 \mathrm{~h}$. Then, the reaction mixture was carefully taken out and $200 \mu \mathrm{L}$ of DMSO was added in each well and mixed gently by pipetting up and down. The absorbance of plates was measured at $550 \mathrm{~nm}$.

\section{Cytotoxicity Assessment by Neutral Red Uptake (NRU) Assay}

Neutral red uptake (NRU) assay was performed according to the method described (Siddiqui et al., 2008). In brief, cells were exposed to various concentrations of compounds of $D$. villosa for $24 \mathrm{~h}$. After the exposure, the test solution was aspirated and cells were washed twice with PBS and incubated further in medium containing $50 \mu \mathrm{g} / \mathrm{mL}$ neutral red for $3 \mathrm{~h}$. Then, the medium was washed with a solution of $\mathrm{CaCl}_{2}(1 \%)$ and formaldehyde $(0.5 \%)$. Following $20 \mathrm{~min}$ incubation at $37^{\circ} \mathrm{C}$ in a mixture of acetic acid (1\%) and ethanol (50\%), the plates were read at $550 \mathrm{~nm}$.

\section{Morphological Changes by Phase Contrast Microscope}

The alterations in the morphology was observed under the inverted microscope to determine the changes induced by compounds of $D$. villosa in HepG2 cells exposed to $10-50 \mu \mathrm{M}$ for $24 \mathrm{~h}$. The cell images were grabbed using phase contrast inverted microscope (Olympus) at $20 \times$ magnification.

\section{Glutathione (GSH) Level}

The level of glutathione in HepG2 cells was measured following the method (Chandra et al., 2002). In brief, HepG2 cells were exposed to $50 \mu \mathrm{M}$ of the compounds of D. villosa for $24 \mathrm{~h}$ and then $\mathrm{H}_{2} \mathrm{O}_{2}(0.25 \mathrm{mM})$ for $24 \mathrm{~h}$. After respective exposure, cells were centrifuged and cellular protein was precipitated with $1 \mathrm{~mL}$ TCA $(10 \%)$ on ice for $1 \mathrm{~h}$. Supernatant was taken by centrifugation at $956 \times g$ for $10 \mathrm{~min}$. Then, $2 \mathrm{~mL}$ of $0.4 \mathrm{M}$ Tris buffer ( $\mathrm{pH}$ 8.9) containing $0.02 \mathrm{M}$ EDTA and $0.01 \mathrm{M} \mathrm{5,5^{ \prime } -}$ dithionitrobenzoic acid (DTNB) were added in the supernatant. 


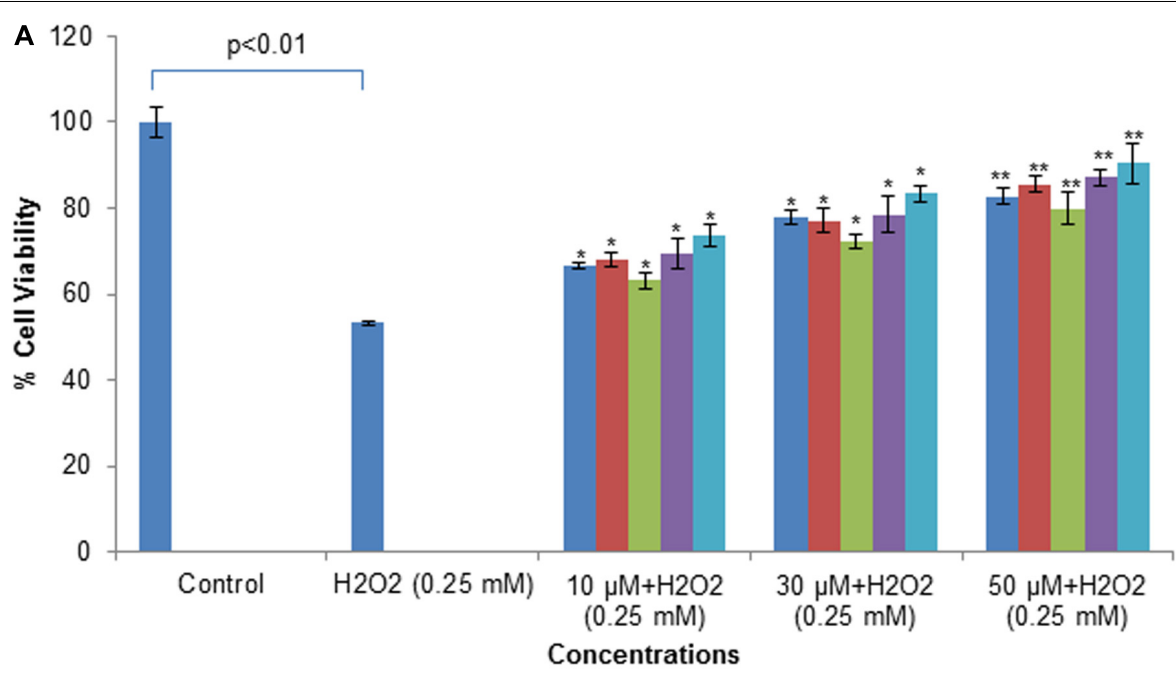

$\square$ Huangjiangsu $\mathrm{A} \backsim$ Pseudoprotodioscin $\square$ Methyl protobioside $₫$ Protodioscin $₫$ Protodeltonin

B

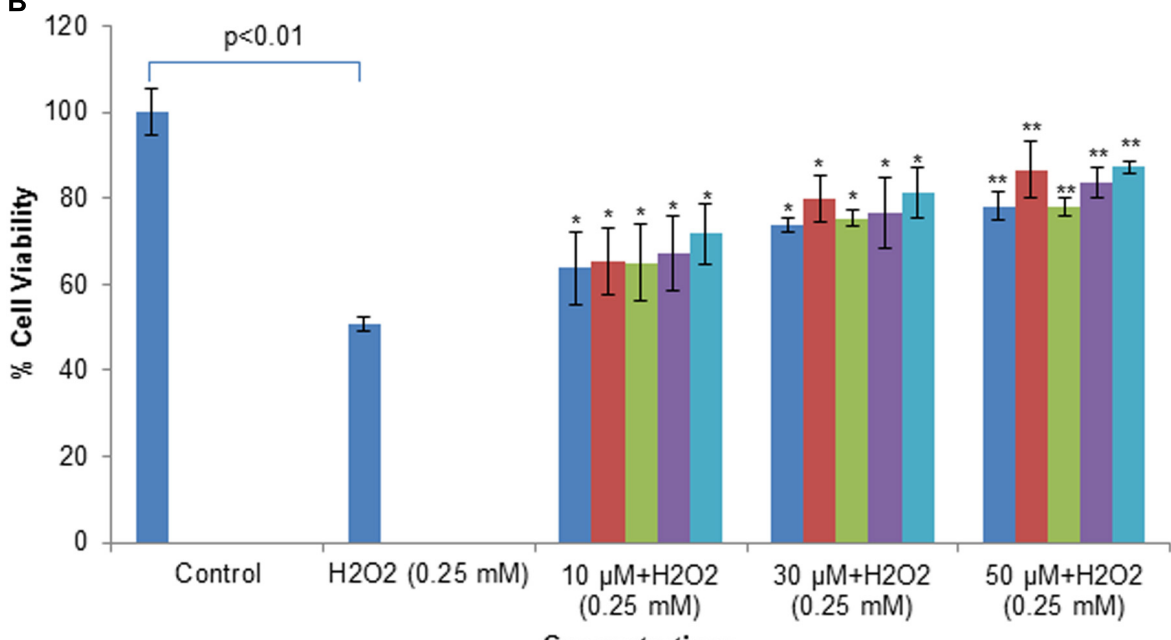

- Huangjiangsu A $\approx$ Pseudoprotodioscin $\approx$ Methyl protobioside $\approx$ Protodioscin $\approx$ Protodeltonin

FIGURE 5 | Assessment of protective potential of compounds on cell viability of HepG2 cells by (A) MTT assay and (B) NRU assay. Cells were exposed to 10, 30, and $50 \mu \mathrm{M}$ of non-cytotoxic compounds for $24 \mathrm{~h}$. Then the cells were exposed to $\mathrm{H}_{2} \mathrm{O}_{2}$ at $0.25 \mathrm{mM}$ for $24 \mathrm{~h}$. All values are given as mean $\pm \mathrm{SD}$. ${ }^{*} p<0.05$, ** $p<0.01$ versus $\mathrm{H}_{2} \mathrm{O}_{2}$.

The absorbance of the developed yellow color was read at $412 \mathrm{~nm}$ after incubating for $10 \mathrm{~min}$ at $37^{\circ} \mathrm{C}$.

\section{Reactive Oxygen Species (ROS) Generation}

The intracellular ROS generation was measured using 2,7dichlorodihydrofluorescein diacetate (DCFH-DA) dye (Siddiqui et al., 2013). HepG2 cells were exposed to $50 \mu \mathrm{M}$ of the compounds for $24 \mathrm{~h}$ and then $\mathrm{H}_{2} \mathrm{O}_{2}(0.25 \mathrm{mM})$ was added in the medium containing compounds for $24 \mathrm{~h}$. After the respective exposure, HepG2 cells were washed with $\mathrm{PBS}$ and incubated with DCFH-DA $(5 \mu \mathrm{M})$ at $37^{\circ} \mathrm{C}$ for $1 \mathrm{~h}$ in dark. The fluorescence of cells was analyzed using a fluorescence microscope (Olympus).

\section{Statistical Analysis}

Data were statistically analyzed by ANOVA and results are presented as mean \pm standard deviation (SD) of three separate experiments $(N=6)$. The treated and control groups were compared using the post hoc Dunnett's test using statistical analysis software GraphPad Prism and considered a significant level of $p<0.05$.

\section{RESULTS AND DISCUSSION}

\section{Compounds}

The molecular formula, $\mathrm{C}_{51} \mathrm{H}_{82} \mathrm{O}_{21}$, of pseudoprotodioscin was determined from an $[\mathrm{M}+\mathrm{Na}]^{+}$ion peak in the HRESIMS at 


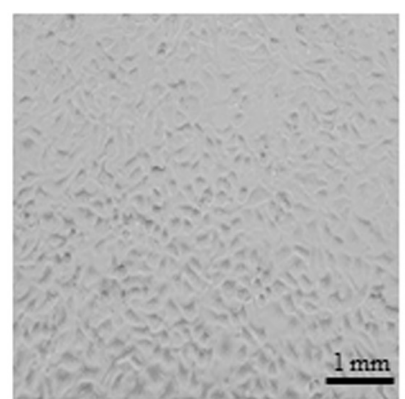

Control

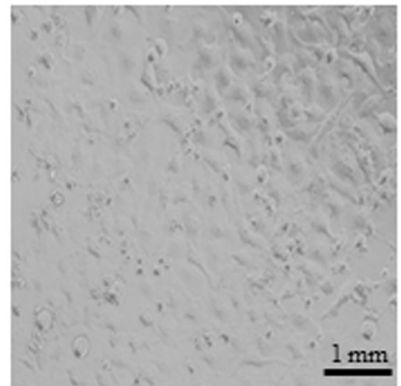

Huangjiangsu $\mathrm{A}(50 \mu \mathrm{M})+\mathrm{H}_{2} \mathrm{O}_{2}$

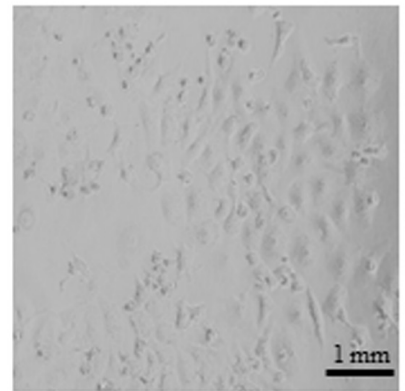

Methyl protobioside $(10 \mu \mathrm{M})+\mathrm{H}_{2} \mathrm{O}_{2}$

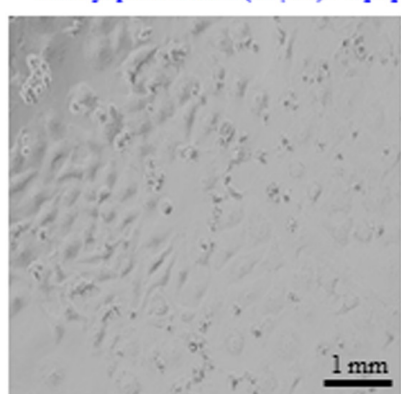

Protodeltonin $(30 \mu \mathrm{M})+\mathrm{H}_{2} \mathrm{O}_{2}$

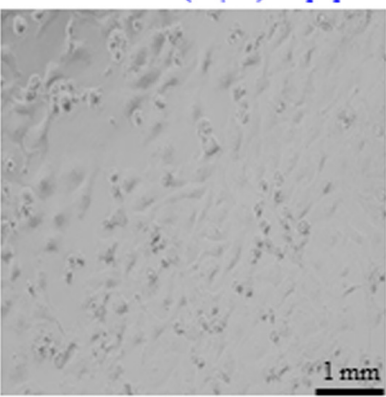

Protodioscin $(50 \mu \mathrm{M})+\mathrm{H}_{2} \overline{\mathrm{O}}$

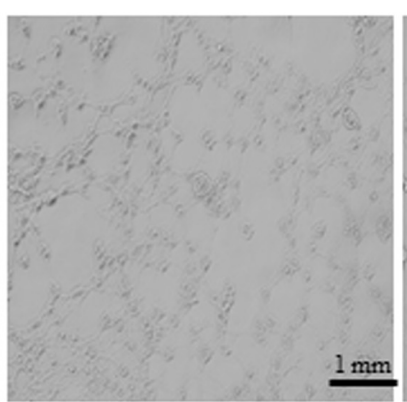

$\mathrm{H}_{2} \mathrm{O}_{2}(0.25 \mathrm{mM})$

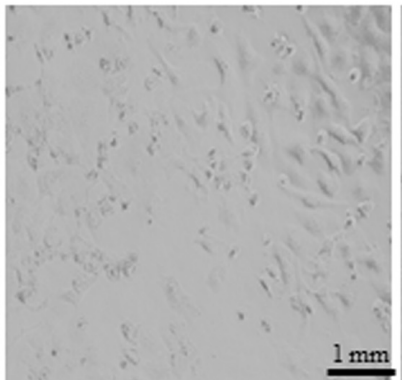

Psevdoprotodioscin $(10 \mu \mathrm{M})+\mathrm{H}_{2} \mathrm{O}_{2}$

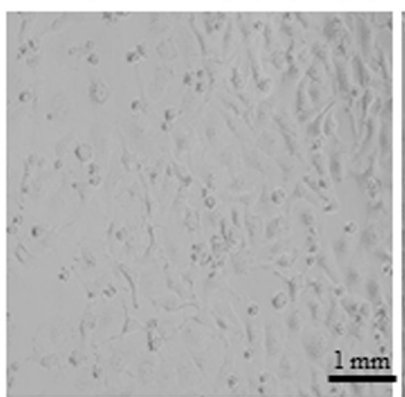

Methyl protobioside $(30 \mu \mathrm{M})+\mathrm{H}_{2} \mathrm{O}_{2}$

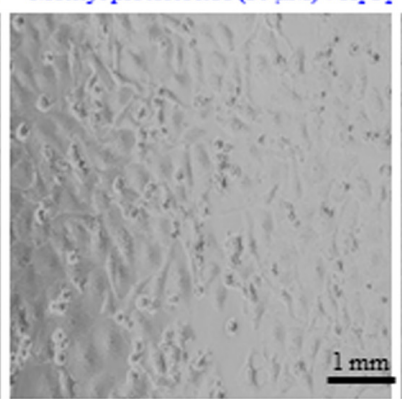

Protodeltonin $(50 \mu \mathrm{M})+\mathrm{H}_{2} \mathrm{O}_{2}$

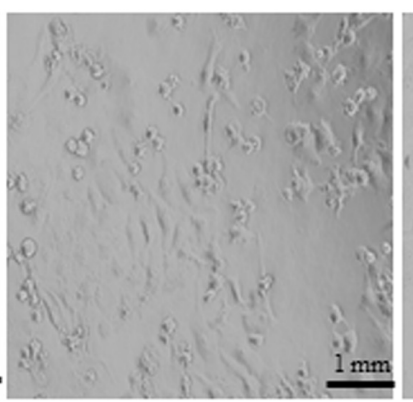

Huangiangsu $\mathrm{A}(10 \mu \mathrm{M})+\mathrm{H}_{2} \mathrm{O}_{2}$

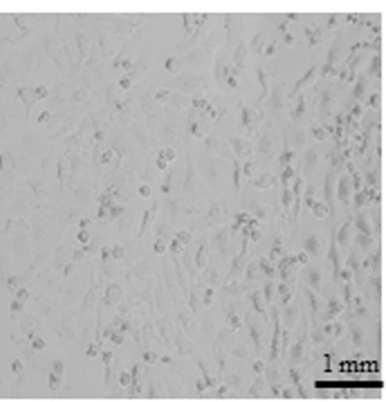

Huangjiangsu $\mathrm{A}(30 \mu \mathrm{M})+\mathrm{H}_{2} \mathrm{O}_{2}$
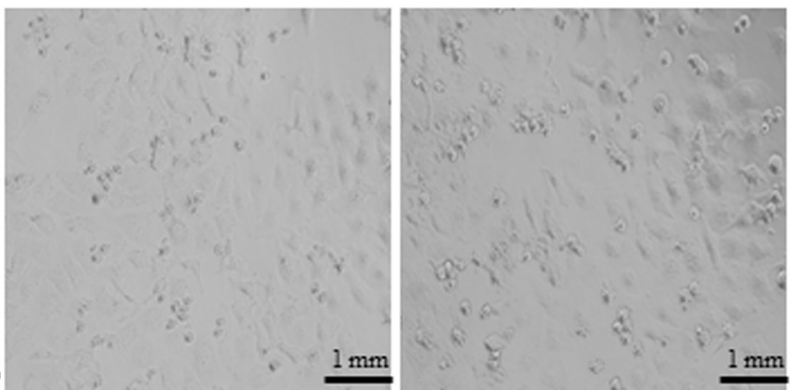

Psevdoprotodioscin $(30 \mathrm{uM})+\mathrm{H}_{2} \mathrm{O}_{2}$
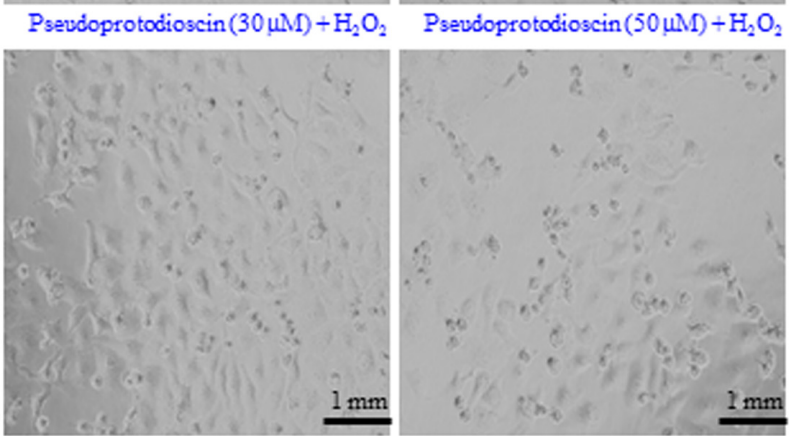

Methyl protobioside $(50 \mu M)+\mathrm{H}_{2} \mathrm{O}_{2}$

\section{Protodeltonin $(10 \mu \mathrm{M})+\mathrm{H}_{2} \mathrm{O}_{2}$}

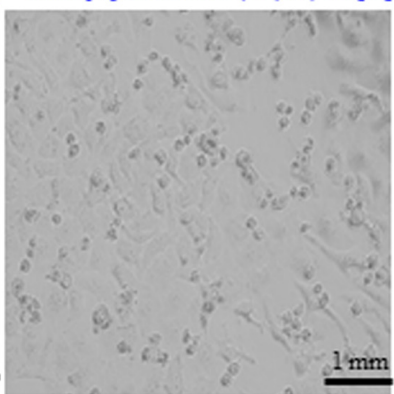

Protodioscin $(10 \mu \mathrm{M})+\mathrm{H}_{2} \mathrm{O}_{2}$

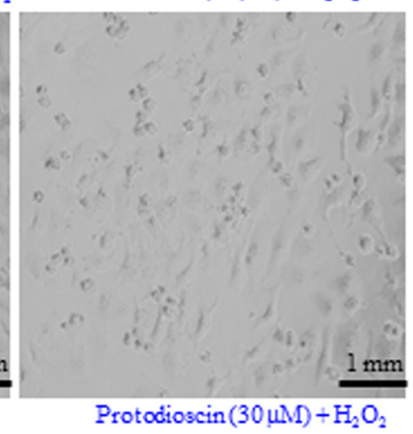

FIGURE 6 | Morphological changes observed in HepG2 cells. Cells were pre-exposed with non-cytotoxic compounds for $24 \mathrm{~h}$ and then $\mathrm{H}_{2} \mathrm{O}_{2}(0.25 \mathrm{mM})$ for $24 \mathrm{~h}$. Images were acquired using a phase contrast inverted microscope at $20 \times$ magnification. Each scale bar $=1 \mathrm{~mm}$. 


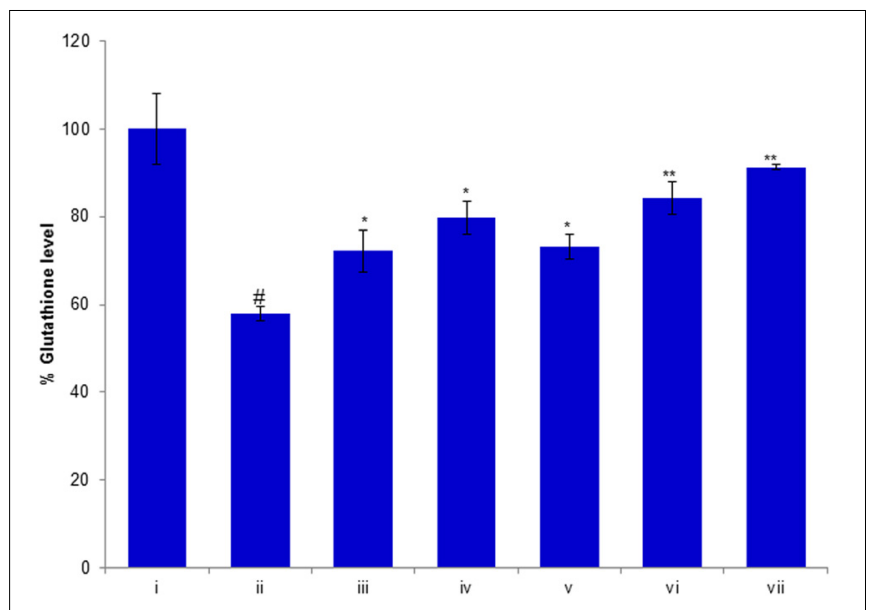

FIGURE 7 | Protective potential of compounds isolated from Dioscorea villosa on depletion in glutathione level. HepG2 cells were exposed to $50 \mu \mathrm{M}$ of non-cytotoxic compounds for $24 \mathrm{~h}$ prior to the addition of $\mathrm{H}_{2} \mathrm{O}_{2}$ for $24 \mathrm{~h}$. All values are represented as mean $\pm \mathrm{SD}$. (i) Control; (ii) $\mathrm{H}_{2} \mathrm{O}_{2}(0.25 \mathrm{mM})$; (iii) Huangjiangsu $\mathrm{A}(50 \mu \mathrm{M})+\mathrm{H}_{2} \mathrm{O}_{2}(0.25 \mathrm{mM})$; (iv) Pseudoprotodioscin $(50 \mu \mathrm{M})+\mathrm{H}_{2} \mathrm{O}_{2}(0.25 \mathrm{mM}) ;(\mathbf{v})$ Methyl protobioside $(50 \mu \mathrm{M})+\mathrm{H}_{2} \mathrm{O}_{2}$ (0.25 mM); (vi) Protodioscin $(50 \mu \mathrm{M})+\mathrm{H}_{2} \mathrm{O}_{2}(0.25 \mathrm{mM})$; and (vii) Protodeltonin $(50 \mu \mathrm{M})+\mathrm{H}_{2} \mathrm{O}_{2}(0.25 \mathrm{mM})$. $\# p<0.01$ versus control, ${ }^{*} p<0.05$ and ${ }^{* *} p<0.01$ versus $\mathrm{H}_{2} \mathrm{O}_{2}$ exposure.

$m / z 1053.5347$ and 51 carbon resonances in its ${ }^{13} \mathrm{C} \mathrm{NMR}$ spectrum attributable to furostan steroid and four sugar units. Its structure was elucidated by analyzing 1D and 2D NMR spectral data which were comparable with those of published in the literature (Yoshikawa et al., 2007). An $[\mathrm{M}+\mathrm{H}]^{+}$ion peak at $\mathrm{m} / z$ 1047.5482 in the HRESIMS and 51 carbon resonances (ascribable to furostan steroid and four sugar units) in the ${ }^{13} \mathrm{C} \mathrm{NMR}$ spectrum of huangjiangsu A, established its molecular formula as $\mathrm{C}_{51} \mathrm{H}_{82} \mathrm{O}_{22}$. Its structure was elucidated by analyzing the NMR data, which were analogous to those of published in the literature (Ali et al., 2013c). Methyl protobioside (Silva et al., 1998; Shen et al., 2002), protodioscin (Shao et al., 1997), and protodeltonin (Munafo et al., 2010) were also identified as furostan steroid glycosides by comparing their NMR data with those of reported. Methyl protobioside, protodioscin, and protodeltonin showed $[\mathrm{M}+\mathrm{Na}]^{+}$ion peaks in their HRESI mass spectra at $\mathrm{m} / z 939.5056$ (corresponded to molecular formula of $\mathrm{C}_{46} \mathrm{H}_{76} \mathrm{O}_{18}$ ), $\mathrm{m} / z$ 1071.5453 (corresponded to molecular formula of $\mathrm{C}_{51} \mathrm{H}_{84} \mathrm{O}_{22}$ ), and $\mathrm{m} / \mathrm{z} 1087.5383$ (corresponded to molecular formula of $\mathrm{C}_{51} \mathrm{H}_{84} \mathrm{O}_{23}$ ), respectively. Zingiberensis saponin I, progenin III, dioscin, and deltonin were identified as spirostan steroidal glycosides by analyzing their $1 \mathrm{D}$ and 2D NMR spectroscopic and HRESIMS spectrometric data as well as by comparing their NMR data with those of published in the literature (Hayes et al., 2007). The HRESI mass spectra of zingiberensis saponin I, progenin III, dioscin, and deltonin displayed $[\mathrm{M}+\mathrm{Na}]^{+}$ ion peaks at $m / z 1069.5209\left(\mathrm{C}_{51} \mathrm{H}_{82} \mathrm{O}_{22}+\mathrm{Na}\right), m / z 745.4219$ $\left(\mathrm{C}_{39} \mathrm{H}_{62} \mathrm{O}_{12}+\mathrm{Na}\right), m / z 891.4803\left(\mathrm{C}_{45} \mathrm{H}_{72} \mathrm{O}_{16}+\mathrm{Na}\right)$, and $m / z$ $907.4587\left(\mathrm{C}_{45} \mathrm{H}_{72} \mathrm{O}_{17}+\mathrm{Na}\right)$, respectively. The structures of the isolated compounds are given in Figure $\mathbf{1}$ and their purities were found to be over $95 \%$, except for protodioscin ( $90 \%$ pure).

\section{Cytotoxicity Assessment of Compounds and $\mathrm{H}_{2} \mathrm{O}_{2}$}

The cytotoxic effects of compounds have been assessed by MTT assay and morphological changes. The results (Figures 2, 3) showed that huangjiangsu A, pseudoprotodioscin, methyl protobioside, protodioscin, and protodeltonin (furostane-type steroidal glycosides) did not cause any effects on cell viability of HepG2 cells (Figure 2A) at 10-50 $\mu \mathrm{M}$ concentrations. However, some compounds, i.e., zingiberensis saponin I (furostanetype steroidal glycoside), dioscin, deltonin, and progenin III (spirostane-type steroidal glycosides) were found to be cytotoxic (Figure 2B). Moreover, the cytotoxic compounds induced cell damage was complemented by changes in cell morphology as observed in the loss of the characteristics in round form; however, no change was observed in non-cytotoxic compounds at highest concentration, i.e., $50 \mu \mathrm{M}$ (Figure 3). Further, the noncytotoxic compounds were selected to study the hepatoprotective effect against $\mathrm{H}_{2} \mathrm{O}_{2}$-induced cytotoxicity in HepG2 cells. As shown in Figure 4, $\mathrm{H}_{2} \mathrm{O}_{2}$ ranging from 0.05 to $2 \mathrm{mM}$ induced cell death in a concentration-dependent manner. Based on the cytotoxicity data, the $0.25 \mathrm{mM}$ concentration of $\mathrm{H}_{2} \mathrm{O}_{2}$-induced cytotoxicity in a moderate manner, therefore, this concentration $(0.25 \mathrm{mM})$ of $\mathrm{H}_{2} \mathrm{O}_{2}$ was used for all further experiments. The results of this study are consistent with the previous reports of concentration-dependent cytotoxicity of $\mathrm{H}_{2} \mathrm{O}_{2}$ in HepG2 (AlSheddi et al., 2016) and other cells (Sattayasai et al., 2013). These studies also demonstrated that $\mathrm{H}_{2} \mathrm{O}_{2}$ could be used as a substance to induce oxidative stress mediated cytotoxicity in cell system.

\section{Cytoprotective Potential of Compounds Against $\mathrm{H}_{2} \mathrm{O}_{2}$-Induced Cytotoxicity}

To illustrate cytoprotective effects of the non-cytotoxic compounds (huangjiangsu A, pseudoprotodioscin, methyl protobioside, protodioscin, and protodeltonin) on cell viability of HepG2 cells against cytotoxicity induced by the $\mathrm{H}_{2} \mathrm{O}_{2}$, the HepG2 cells were incubated with 10, 30, and $50 \mu \mathrm{M}$ concentrations of test compounds for $24 \mathrm{~h}$ and then with cytotoxic concentration $(0.25 \mathrm{mM})$ of $\mathrm{H}_{2} \mathrm{O}_{2}$. The $\mathrm{H}_{2} \mathrm{O}_{2}$-induced cell death and hepatoprotective effect were determined by MTT and NRU assays and morphological changes. The protective potential of each compound as observed in HepG2 cells is presented in Figure 5. A significant $(p<0.01)$ reduction in cell viability was observed in HepG2 cells following the exposure with $\mathrm{H}_{2} \mathrm{O}_{2}(0.25 \mathrm{mM})$ for $24 \mathrm{~h}$ by MTT assay (Figure 5A), and NRU assay (Figure 5B). However, a concentration-dependent increase in the cell viability was observed in HepG2 cells pre-exposed to huangjiangsu A, pseudoprotodioscin, methyl protobioside, protodioscin, and protodeltonin compounds at 10,30 , and $50 \mu \mathrm{M}$ for $24 \mathrm{~h}$. The increase in cell viability was observed to be 13,24 , and $29 \%$ by huangjiangsu $A ; 15,24$, and $32 \%$ by pseudoprotodioscin; 10,19 , and $26 \%$ by methyl protobioside; 16,25 , and $34 \%$ by protodioscin; and 20, 30, and $37 \%$ by protodeltonin at 10,30 , and $50 \mu \mathrm{M}$, respectively, in pre-exposed HepG2 cells (Figure 5A). Similar to MTT assay, a concentration-dependent protective effect was also observed 

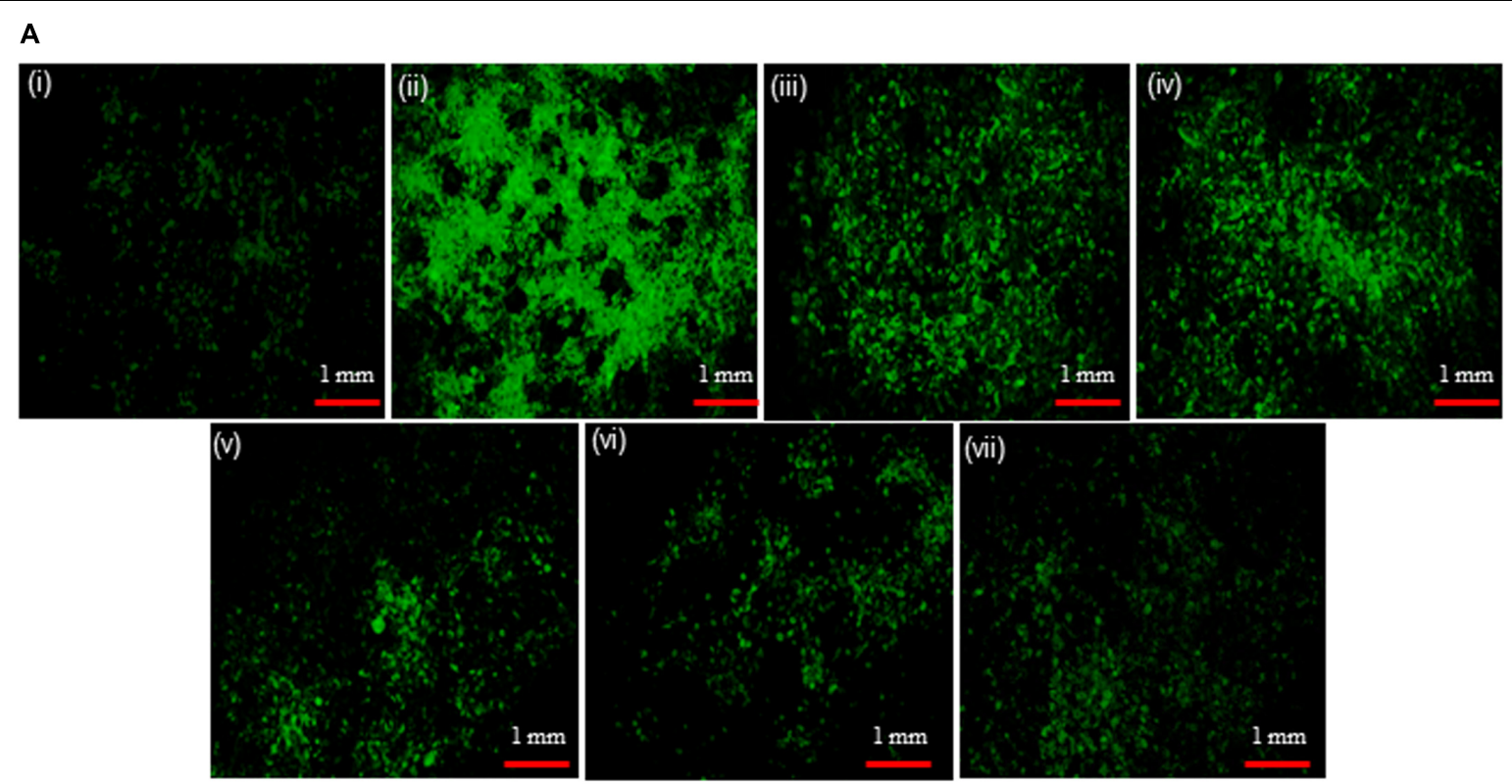

B

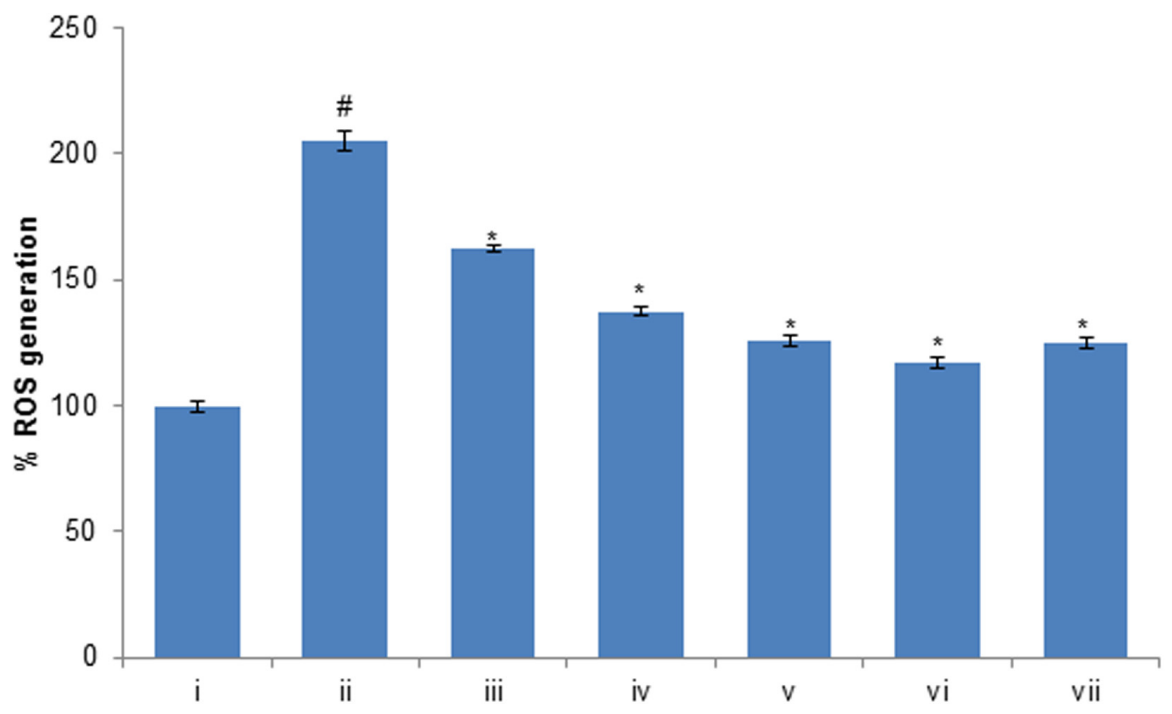

FIGURE 8 | (A) $\mathrm{H}_{2} \mathrm{O}_{2}$-induced ROS generation and ameliorative effect of pre-treatment of compounds in HepG2 cells and (B) percent change in ROS generation. ROS generation was evaluated using dichlorodihydrofluorescein diacetate (DCFH-DA) dye. (i) Untreated control; (ii) $\mathrm{H}_{2} \mathrm{O}_{2}(0.25 \mathrm{mM}$ ); (iii) $\mathrm{Huangjiangsu} \mathrm{A}$ $(50 \mu \mathrm{M})+\mathrm{H}_{2} \mathrm{O}_{2}(0.25 \mathrm{mM})$; (iv) Pseudoprotodioscin $(50 \mu \mathrm{M})+\mathrm{H}_{2} \mathrm{O}_{2}(0.25 \mathrm{mM})$; (v) Methyl protobioside $(50 \mu \mathrm{M})+\mathrm{H}_{2} \mathrm{O}_{2}(0.25 \mathrm{mM}) ;$ (vi) Protodioscin $(50 \mu \mathrm{M})+\mathrm{H}_{2} \mathrm{O}_{2}(0.25 \mathrm{mM})$; and (vii) Protodeltonin $(50 \mu \mathrm{M})+\mathrm{H}_{2} \mathrm{O}_{2}(0.25 \mathrm{mM}) .{ }^{\#} p<0.01$ versus control, ${ }^{*} p<0.05$ versus $\mathrm{H}_{2} \mathrm{O}_{2}$ exposure. Each scale bar $=1 \mathrm{~mm}$.

in NRU assay. The increase in cell viability by NRU assay was observed to be 13,23 , and $28 \%$ by huangjiangsu A; 15,30 , and $36 \%$ by pseudoprotodioscin; 14,25 , and $28 \%$ by methyl protobioside; 17,26 , and $33 \%$ by protodioscin; and 21,31 , and $37 \%$ by protodeltonin at 10,30 , and $50 \mu \mathrm{M}$ concentrations, respectively, in pre-exposed HepG2 cells (Figure 5B). The results of this study showed that pre-exposure of cells to the test compounds significantly increased the viability of HepG2 cells against $\mathrm{H}_{2} \mathrm{O}_{2}$-induced cell death. Our results support the previous studies that compounds isolated from natural products exhibited significant hepatoprotective effects against $\mathrm{H}_{2} \mathrm{O}_{2}$ (Xia et al., 2017) and against other toxicants such as acetaminophen and $\mathrm{CCl}_{4}$ (González et al., 2017). Several studies have also demonstrated that various compounds isolated from plants exhibited prominent cytoprotective potential against $\mathrm{H}_{2} \mathrm{O}_{2}$-induced cell death in different cell system (Yang et al., 2015b; Wang et al., 2015).

\section{Morphological Changes}

The morphological changes observed in HepG2 cells pre-exposed to compounds from D. villosa and then $\mathrm{H}_{2} \mathrm{O}_{2}$ for $24 \mathrm{~h}$ are summarized in Figure 6. As shown in the figure, $\mathrm{H}_{2} \mathrm{O}_{2}$ at $0.25 \mathrm{mM}$ concentration induced characteristic morphological changes, such as cell shrinkage, appearance as rounded bodies 
and loss of adhesion capacity as compared to the control. However, HepG2 cells pre-exposed to 10, 30, and $50 \mu \mathrm{M}$ concentrations of huangjiangsu A, pseudoprotodioscin, methyl protobioside, protodioscin, and protodeltonin restored their original morphology similar to the control in a concentrationdependent manner. The preservation of the normal morphology of HepG 2 cells observed by phase contrast microscope indicated the preventive role of the compounds against $\mathrm{H}_{2} \mathrm{O}_{2}$-induced morphological damage.

\section{Protective Potential of Compounds Against $\mathrm{H}_{2} \mathrm{O}_{2}$ Reduced GSH Level}

In order to evaluate the effects of compounds of $D$. villosa on antioxidant defense systems, the glutathione (GSH) level was measured in $\mathrm{H}_{2} \mathrm{O}_{2}$ exposed HepG2 cells. The results of this study showed that GSH level in $\mathrm{H}_{2} \mathrm{O}_{2}$ exposed HepG2 cells was significantly decreased by $43 \%(p<0.01)$ as compared to the control (Figure 7). However, as shown in the figure, pre-exposure of cells to huangjiangsu A, pseudoprotodioscin, methyl protobioside, protodioscin, and protodeltonin at $50 \mu \mathrm{M}$ concentration significantly increased the $\mathrm{GSH}$ level in $\mathrm{H}_{2} \mathrm{O}_{2}$ exposed HepG2 cells. The increase in GSH level was 15\% by huangjiangsu $\mathrm{A}, 22 \%$ by pseudoprotodioscin, $16 \%$ by methyl protobioside, $27 \%$ by protodioscin, and $34 \%$ by protodeltonin at $50 \mu \mathrm{M}$ (Figure 7). Our results showed that pre-exposure of cells to the test compounds effectively restored the GSH level. It is well known that exogenous exposure of $\mathrm{H}_{2} \mathrm{O}_{2}$ can increase the intracellular ROS generation and induced cellular oxidative damage in hepatic cells and it can be eliminated by hepatocyte antioxidant defense mechanisms (Xia et al., 2017). GSH is a main non-enzymatic antioxidant, which plays an important role in the cellular defense system against oxidative stress (Scharf et al., 2003). It has been reported that glutathione peroxidase catalyses GSH oxidation to GSSG at the expense of $\mathrm{H}_{2} \mathrm{O}_{2}$ and glutathione reductase recycles oxidized $\mathrm{GSH}$ back to reduced GSH (Al-Sheddi et al., 2016). Thus, it could be concluded that the pre-exposure of HepG2 cells to these compounds quenches the intracellular destructive peroxide and increases the level of glutathione thus enhancing the antioxidant status and protecting the cells against the $\mathrm{H}_{2} \mathrm{O}_{2}$-induced damage.

\section{Protective Potential of Compounds Against $\mathrm{H}_{2} \mathrm{O}_{2}$-Induced ROS Generation}

The level of intracellular ROS generation in HepG2 cells was evaluated using a DCFH-DA fluorescent probe. The HepG2 cells were pre-exposed to $50 \mu \mathrm{M}$ of compounds (huangjiangsu A, pseudoprotodioscin, methyl protobioside, protodioscin, and protodeltonin) for $24 \mathrm{~h}$ and then $\mathrm{H}_{2} \mathrm{O}_{2}$ for $24 \mathrm{~h}$. The results showed that the DCF fluorescence intensity in $\mathrm{H}_{2} \mathrm{O}_{2}$-treated HepG2 cells was significantly increased to $104 \%$ as compared to the control group (Figure 8). However, the fluorescence intensity was notably reduced up to $42,67,79,87$, and $80 \%$ in HepG2 cells pre-exposed to $50 \mu \mathrm{M}$ of huangjiangsu $\mathrm{A}$, pseudoprotodioscin, methyl protobioside, protodeltonin, and protodioscin compounds, respectively (Figure 8). As shown in figure, compound huangjiangsu A showed the highest scavenging activity of intracellular ROS generation. It is reported that exogenous exposure of $\mathrm{H}_{2} \mathrm{O}_{2}$ resulted in accumulation of intracellular ROS generation, which plays an important role in cell differentiation, cell proliferation, and cell death (Park, 2013). ROS generation is well known to be associated with the principle of oxidative stress (Schieber and Chandel, 2014). Oxidative stress is the net result of an imbalance in the amount of ROS generation and destruction, which is involved in causation and consequences of many diseases (Aruoma, 1998; Rodriguez and Redman, 2005). It is also been reported that induction in ROS generation plays an important role in the hepatocellular damage (Jiang et al., 2014). Since $\mathrm{H}_{2} \mathrm{O}_{2}$-induced oxidative stress and ROS generation have been previously reported, we used $\mathrm{H}_{2} \mathrm{O}_{2}$ to induce ROS generation in HepG2 cells. In this study, an increase in the ROS generation indicated that $\mathrm{H}_{2} \mathrm{O}_{2}$ could cause oxidative stress in HepG2 cells. The decrease in the intracellular ROS generation in HepG2 pre-exposed to $50 \mu \mathrm{M}$ showed the protective potential of various compounds against $\mathrm{H}_{2} \mathrm{O}_{2}$-induced ROS generation. Our results are also in accordance with the previous reports showing that the administration of compounds isolated from plant suppresses the level of ROS generation (Yang et al., 2015a).

\section{CONCLUSION}

The present study demonstrated the cytotoxic and cytoprotective potential of selected steroidal glycosides, i.e., zingiberensis saponin I, dioscin, deltonin, progenin III, huangjiangsu A, pseudoprotodioscin, methyl protobioside, protodioscin, and protodeltonin, isolated from D. villosa. Furostane-type steroidal glycosides (huangjiangsu A, pseudoprotodioscin, methyl protobioside, protodioscin, and protodeltonin) were found to attenuate $\mathrm{H}_{2} \mathrm{O}_{2}$-induced cytotoxicity in HepG2 cells. Their protective effect seems to be mediated by inhibiting intracellular ROS generation and restoring the GSH level. Together, results from the present study suggest that the constituents of $D$. villosa can protect HepG2 cells against $\mathrm{H}_{2} \mathrm{O}_{2}$-induced oxidative damage through antioxidant activity.

\section{AUTHOR CONTRIBUTIONS}

MS and IK designed the experiments. ZA, AC, and MS performed the experiments. ZA and MS analyzed the data and drafted the manuscript. IK and AC supervised the study. All the authors read and approved for the publication.

\section{ACKNOWLEDGMENTS}

The authors would like to thank Twasol Research Excellence Program (TRE Program), King Saud University, Riyadh, Saudi Arabia for support. 


\section{REFERENCES}

Ali, Z., Smillie, T. J., and Khan, I. A. (2013a). 7-Oxodioscin, a new spirostan steroid glycoside from the rhizomes of Dioscorea nipponica. Nat. Prod. Commun. 8, 319-321.

Ali, Z., Smillie, T. J., and Khan, I. A. (2013b). Cholestane steroid glycosides from the rhizomes of Dioscorea villosa (wild yam). Carbohydr. Res. 370, 86-91. doi: 10.1016/j.carres.2012.12.022

Ali, Z., Smillie, T. J., and Khan, I. A. (2013c). Two spirostan steroid glycoside fatty esters from Dioscorea cayenensis. Nat. Prod. Commun. 8, 323-326.

Al-Sheddi, E. S., Farshori, N. N., Al-Oqail, M. M., Musarrat, J., Al-Khedhairy, A. A., and Siddiqui, M. A. (2016). Protective effect of Lepidium sativum seed extract against hydrogen peroxide-induced cytotoxicity and oxidative stress in human liver cells (HepG2). Pharm. Biol. 54, 314-321. doi: 10.3109/13880209. 2015.1035795

Aruoma, O. I. (1998). Free radicals, oxidative stress, and antioxidants in human health and disease. J. Am. Oil Chem. Soc. 75, 199-212. doi: 10.1007/s11746998-0032-9

Aumsuwan, P., Khan, S. I., Khan, I. A., Ali, Z., Avula, B., Walker, L. A., et al. (2016). The anticancer potential of steroidal saponin, dioscin, isolated from wild yam (Dioscorea villosa) root extract in invasive human breast cancer cell line MDAMB-231 in vitro. Arch. Biochem. Biophys. 591, 98-110. doi: 10.1016/j.abb.2015. 12.001

Aumsuwan, P., Khan, S. I., Khan, I. A., Avula, B., Walker, L. A., Helferich, W. G., et al. (2015). Evaluation of wild yam (Dioscorea villosa) root extract as a potential epigenetic agent in breast cancer cells. In Vitro Cell. Dev. Biol. Anim. 51, 59-71. doi: 10.1007/s11626-014-9807-5

Bechmann, L. P., Hannivoort, R. A., Gerken, G., Hotamisligil, G. S., Trauner, M., and Canbay, A. (2012). The interaction of hepatic lipid and glucose metabolism in liver diseases. J. Hepatol. 56, 952-964. doi: 10.1016/j.jhep.2011. 08.025

Chandra, D., Ramana, K. V., Wang, L., Christensen, B. N., Bhatnagar, A., and Srivastava, S. K. (2002). Inhibition of fiber cell globulization and hyperglycemiainduced lens opacification by aminopeptidase inhibitor bestatin. Invest. Ophthalmol. Vis. Sci. 43, 2285-2292.

Chaudhari, G. M., and Mahajan, R. T. (2016). In vitro hepatoprotective activity of Terminalia arjuna stem bark and its flavonoids against $\mathrm{CCl} 4$ induced hepatotoxicity in goat liver slice culture. Asian J. Plant Sci. Res. 6, 10-17.

Cheong, C. U., Yeh, C. S., Hsieh, Y. W., Lee, Y. R., Lin, M. Y., Chen, C. Y., et al. (2016). Protective effects of costunolide against hydrogen peroxideinduced injury in PC12 cells. Molecules 21:E898. doi: 10.3390/molecules2107 0898

Gao, X., Li, C., Tang, Y. L., Zhang, H., and Chan, S. W. (2016). Effect of Hedyotis diffusa water extract on protecting human hepatocyte cells (LO2) from H2O2induced cytotoxicity. Pharm. Biol. 54, 1148-1155. doi: 10.3109/13880209.2015. 1056310

González, L. T., Minsky, N. W., Espinosa, L. E. M., Aranda, R. S., Meseguer, J. P., and Pérez, P. C. (2017). In vitro assessment of hepatoprotective agents against damage induced by acetaminophen and CCl4. BMC Complement. Altern. Med. 17:39. doi: 10.1186/s12906-016-1506-1

Haidry, M., and Malik, A. T. (2014). Hepatoprotective and antioxidative effects of Terminalia arjuna against cadmium provoked toxicity in albino rats (Rattus norvegicus). Biochem. Pharmacol. 3, 1-4. doi: 10.4172/2167-0501.100 0130

Hayes, P. Y., Lambert, L. K., Lehmann, R., Penman, K., Kitchin, W., and De Voss, J. J. (2007). Complete $1 \mathrm{H}$ and $13 \mathrm{C}$ assignments of the four major saponins from Dioscorea villosa (wild yam). Magn. Reson. Chem. 45, 1001-1005. doi: 10.1002/mrc.2071

Hong, M., Li, S., Tan, H. Y., Wang, N., Tsao, S. W., and Feng, Y. (2015). Current status of herbal medicines in chronic liver disease therapy: the biological effects, molecular targets and future prospects. Int. J. Mol. Sci. 16, 28705-28745. doi: 10.3390/ijms161226126

Jiang, J., Yu, S., Jiang, Z., Liang, C., Yu, W., Li, J., et al. (2014). N-acetylserotonin protects HepG2 cells from oxidative stress injury induced by hydrogen peroxide. Oxid. Med. Cell. Longev. 2014:310504. doi: 10.1155/2014/ 310504

Jiménez-Arellanes, M. A., Gutiérrez-Rebolledo, G. A., Meckes-Fischer, M., and León-Díaz, R. (2016). Medical plant extracts and natural compounds with a hepatoprotective effect against damage caused by antitubercular drugs: a review. Asian Pac. J. Trop. Med. 9, 1141-1149. doi: 10.1016/j.apjtm.2016. 10.010

Kim, E. A., Jang, J. H., Lee, Y. H., Sung, E. G., Song, I. H., Kim, J. Y., et al. (2014). Dioscin induces caspase-independent apoptosis through activation of apoptosis-inducing factor in breast cancer cells. Apoptosis 19, 1165-1175. doi: 10.1007/s10495-014-0994-z

Kim, J. H., Kim, D., Kim, J., and Hwang, J. K. (2011). Euchresta horsfieldii Benn. activates peroxisome proliferatoractivated receptor a and regulates expression of genes involved in fatty acid metabolism in human HepG2 cells. J. Ethnopharmacol. 133, 244-247. doi: 10.1016/j.jep.2010.09.029

Komesaroff, P. A., Black, C. V. S., Cable, V., and Sudhir, K. (2001). Effects of wild yam extract on menopausal symptoms, lipids and sex hormones in healthy menopausal women. Climacteric 4, 144-150. doi: 10.1080/cmt.4.2. 144.150

Li, S., Tan, H. Y., Wang, N., Zhang, Z. J., Lao, L., Wong, C. W., et al. (2015). The role of oxidative stress and antioxidants in liver diseases. Int. J. Mol. Sci. 16, 26087-26124. doi: 10.3390/ijms161125942

McAnuff, M. A., Harding, W. W., Omoruyi, F. O., Jacobs, H., Morrison, F. Y., and Asemota, H. N. (2005). Hypoglycemic effects of steroidal sapogenins isolated from Jamaican bitter yam, Dioscorea polygonoides. Food Chem. Toxicol. 43, 1667-1672. doi: 10.1016/j.fct.2005.05.008

Munafo, J. P., Ramanathan, A., Jimenez, L. S., and Gianfagna, T. J. (2010). Isolation and structural determination of steroidal glycosides from the bulbs of Easter lily (Lilium longiflorum Thunb.). J. Agric. Food Chem. 58, 8806-8813. doi: $10.1021 /$ jf101410d

Park, W. H. (2013). The effects of exogenous H2O2 on cell death, reactive oxygen species and glutathione levels in calf pulmonary artery and human umbilical vein endothelial cells. Int. J. Mol. Med. 31, 471-476. doi: 10.3892/ijmm.2012. 1215

Pereira, C., Barros, L., and Ferreira, I. C. (2016). Extraction, identification, fractionation and isolation of phenolic compounds in plants with hepatoprotective effects. J. Sci. Food Agric. 96, 1068-1084. doi: 10.1002/jsfa.7446

Ray, P. D., Huang, B. W., and Tsuji, Y. (2012). Reactive oxygen species (ROS) homeostasis and redox regulation in cellular signaling. Cell. Signal. 24, 981-990. doi: 10.1016/j.cellsig.2012.01.008

Rodriguez, R., and Redman, R. (2005). Balancing the generation and elimination of reactive oxygen species. Proc. Natl. Acad. Sci. U.S.A. 102, 3175-3176. doi: $10.1073 /$ pnas.0500367102

Sattayasai, J., Chaonapan, P. T., Arkaravichie, R., Soi-ampornkul, S., Junnu, P., Charoensilp, J., et al. (2013). Protective effects of Mangosteen extract on H2O2-induced cytotoxicity in SK-NSH cells and scopolamine-induced memory impairment in mice. PLoS One 8:e85053. doi: 10.1371/journal.pone. 0085053

Scharf, G., Prustomersky, S., Knasmuller, S., Schulte-Hermann, R., and Huber, W. W. (2003). Enhancement of glutathione and glutamylcysteine synthetase, the rate limiting enzyme of glutathione synthesis, by chemoprotective plant-derived food and beverage components in the human hepatoma cell line HepG2. Nutr. Cancer 45, 74-83. doi: 10.1207/S15327914N C4501_9

Schieber, M., and Chandel, N. S. (2014). ROS function in redox signaling and oxidative stress. Curr. Biol. 24, 453-462. doi: 10.1016/j.cub.2014.03.034

Shao, Y. U., Poobrasert, O., Kennelly, E. J., Chin, C. K., Ho, C. T., Huang, M. T., et al. (1997). Steroidal saponins from Asparagus officinalis and their cytotoxic activity. Planta Med. 63, 258-262. doi: 10.1055/s-2006-957667

Sharma, S. K., Arogya, S. M., Bhaskarmurthy, D. H., Agarwal, A., and Velusami, C. C. (2011). Hepatoprotective activity of the Phyllanthus species on tert-butyl hydroperoxide $(t-\mathrm{BH})$-induced cytotoxicity in HepG2 cells. Pharmacogn. Mag. 7, 229-233. doi: 10.4103/0973-1296.84237

Shen, P., Wang, S. L., Liu, X. K., Yang, C. R., Cai, B., and Yao, X. S. (2002). A new steroidal saponin from Dioscorea deltoidea wall var. orbiculata. Chin. Chem. Lett. 13, 851-854.

Siddiqui, M. A., Ahmad, J., Farshori, N. N., Saquib, Q., Jahan, S., Kashyap, M. P., et al. (2013). Rotenone-induced oxidative stress and apoptosis in human liver HepG2 cells. Mol. Cell Biochem. 384, 59-69. doi: 10.1007/s11010-013-1 781-9

Siddiqui, M. A., Singh, G., Kashyap, M. P., Khanna, V. K., Yadav, S., Chandra, D., et al. (2008). Influence of cytotoxic doses of 4-hydroxynonenal on selected 
neurotransmitter receptors in PC-12 cells. Toxicol. In Vitro 22, 1681-1688. doi: 10.1016/j.tiv.2008.07.001

Silva, B. P., Bernardo, R. R., and Parente, J. P. (1998). New furostanol glycosides from Costus spicatus. Phytochemistry 69, 528-532.

Simeonova, R., Kondeva-Burdina, M., Vitcheva, V., and Mitcheva, M. (2014). Some in vitro/in vivo chemically-induced experimental models of liver oxidative stress in rats. BioMed Res. Int. 2014:706302. doi: 10.1155/2014/70 6302

Videla, L. A. (2009). Oxidative stress signaling underlying liver disease and hepatoprotective mechanisms. World J. Hepatol. 1, 72-78. doi: 10.4254/wjh.v1. i1.72

Wang, J., Zhao, Y. M., Zhang, B., and Guo, C. Y. (2015). Protective effect of total phenolic compounds from Inula helenium on hydrogen peroxide-induced oxidative stress in SH-SY5Y cells. Indian J. Pharm. Sci. 77, 163-169. doi: 10. 4103/0250-474X.156553

Xia, T., Yao, J., Zhang, J., Zheng, Y., Song, J., and Wang, M. (2017). Protective effects of Shanxi aged vinegar against hydrogen peroxide-induced oxidative damage in LO2 cells through Nrf2-mediated antioxidant responses. RSC Adv. 7, 17377-17386. doi: 10.1039/C6RA27789F

Xu, T., Zhang, S., Zheng, L., Yin, L., Xu, L., and Peng, P. A. (2012). 90-day subchronic toxicological assessment of dioscin, a natural steroid saponin, in Sprague-Dawley rats. Food Chem. Toxicol. 50, 1279-1287. doi: 10.1016/j.fct. 2012.02.027
Yang, J., Kwon, Y. S., and Kim, M. J. (2015a). Isolation and characterization of bioactive compounds from Lepisorus thunbergianus (Kaulf.). Arab. J. Chem. 8, 407-413. doi: 10.1016/j.arabjc.2014.11.056

Yang, D., Liu, X., Liu, M., Chi, H., Liu, J., and Han, H. (2015b). Protective effects of quercetin and taraxasterol against $\mathrm{H} 2 \mathrm{O} 2$-induced human umbilical vein endothelial cell injury in vitro. Exp. Ther. Med. 10, 1253-1260. doi: 10.3892/ etm.2015.2713

Yoshikawa, M., Xu, F., Morikawa, T., Pongpiriyadacha, Y., Nakamura, S., Asao, Y., et al. (2007). Medical flowers. XII. New spirostane-type steroid saponins with antidiabetogenic activity from Borassus flabellier. Chem. Pharm. Bull. 55, 308316. doi: $10.1248 / \mathrm{cpb} .55 .308$

Conflict of Interest Statement: The authors declare that the research was conducted in the absence of any commercial or financial relationships that could be construed as a potential conflict of interest.

Copyright $\odot 2018$ Siddiqui, Ali, Chittiboyina and Khan. This is an open-access article distributed under the terms of the Creative Commons Attribution License (CC BY). The use, distribution or reproduction in other forums is permitted, provided the original author(s) and the copyright owner(s) are credited and that the original publication in this journal is cited, in accordance with accepted academic practice. No use, distribution or reproduction is permitted which does not comply with these terms. 